\title{
www.czasopisma.pan.pl \\ Effective Laboratory Method of Chromite Content Estimation in Reclaimed Sands
}

\author{
Z. Ignaszak ${ }^{a *}$, J-B. Prunier ${ }^{b}$ \\ ${ }^{a}$ CAD/CAE Laboratory, Division of Foundry, Poznan University of Technology, \\ Piotrowo 3, 61-138 Poznań, Poland \\ ${ }^{\mathrm{b}}$ Metallurgical Group CIF Ferry-Capitain, France \\ *Corresponding author. E-mail address: zenon.ignaszak@put.poznan.pl
}

Received 07.04.2016; accepted in revised form 04.06.2016

\begin{abstract}
The paper presents an original method of measuring the actual chromite content in the circulating moulding sand of foundry. This type of material is applied for production of moulds. This is the case of foundry which most frequently perform heavy casting in which for the construction of chemical hardening mould is used, both the quartz sand and chromite sand. After the dry reclamation of used moulding sand, both types of sands are mixed in various ratios resulting that in reclaimed sand silos, the layers of varying content of chromite in mixture are observed. For chromite recuperation from the circulating moulding sand there are applied the appropriate installations equipped with separate elements generating locally strong magnetic field. The knowledge of the current ratio of chromite and quartz sand allows to optimize the settings of installation and control of the separation efficiency. The arduous and time-consuming method of determining the content of chromite using bromoform liquid requires operational powers and precautions during using this toxic liquid. It was developed and tested the new, uncomplicated gravimetric laboratory method using powerful permanent magnets (neodymium). The method is used in the production conditions of casting for current inspection of chromite quantity in used sand in reclamation plant.
\end{abstract}

Keywords: Chromite sand, Magnetic recuperation, Neodymium magnets, Furan sand dry reclamation, Ferrous alloys, Heavy castings

\section{Introduction}

The ensuring of heavy castings quality, especially in steel foundry, the quality defined by customer requirement conditions is high challenge for foudrymen. Already at the stage of concept technology elaboration the problems are not only related to the assurance of high metallurgical alloy quality but other problems must be solved. It is necessary simultaneously to take care of the professional and rational management of large moulding sand volume (few thousand tons even for middle foundry class). It should be considered the size of castings (presence time in the mould after pouring), applied technologies and the variety of matrices and chemically hardened binder systems. A few aspects resulting from the theoretical basis of knowledge concerning the moulding sands and practical knowledge, under which the authors worked of this paper, was highlighted in [1-5]. It's inspired to undertake further tests in the same Metallurgical Group of French foundries (volume weight in circulation over 2000 tones), but also in foundries and research institutes in Poland [6-8].

In the paper the problem resulting from the presence of the chromite sand in the used circulating moulding sand was analyzed. The chromite sand is used to increase of local refractoriness of the mould/core zone, thereby preventing in this way the formation of important surface defects which disqualify the casting and deep steel penetrating in surface layers of the mould [2]. However, when knocking out the casting, the mould materials, including chromite sand are mixed in random 
proportions with quartz sand. The quantity of chromite in the circulation of matter varies from few to several \%.

After classic dry reclamation, such a moulding sand (mixture quartz/chromite) can not be used as a contact sand with the liquid metal (steel) in the mould cavity. As known, in the case of a minimum share of chromite sand in the circulating moulding sand (over 2\%) generate the defects as metal penetration due to the deep penetration of the liquid steel into the porous structure of the moulding sand, caused by the formation of low-melting eutectics containing $\mathrm{FeO}$ and $\mathrm{SiO}_{2}$ oxides. The use of the effective magnetic separation described among others in [9] is an effective way to reduce the chromite content in circulating moulding sand. However, there are limitations and conditions of use of such devices in a sand reclamation system plants. The efficiency of available equipment and installations for magnetic separation is considerably too low to eliminate the operation of chromite of the circulating moulding sand undergo the entire volume of the circulating moulding sand. Thus, knowledge of the current ratio of chromite and silica sand allows to optimize the settings of the magnetic installation and control of the separation efficiency. It is also important from the point of view of current control of the chromite content and profitability or start parameters of this installation in the foundry.

The paper refers to the method of determination of chromite quantity by classical densitometric method, requiring special industrial safety authorization by external national organizations and special laboratory equipment. It was developed and tested a new, uncomplicated laboratory gravimetric method, using powerful permanent magnets. The method was definitively used in the foundry production conditions for current inspection of chromite quantity in used sand in reclamation plant.

\section{Conditions of application and reclamation of chromite sand from circulating moulding sand. State of arts}

The application of chromite sand results from the favorable properties of the mineral called chromite. The chromite is primarily a raw material for the production of ferro-chromium, using different metallurgical methods [10] and is a naturally occurring spinel consisting primarily of the oxides of chrome and iron. As to the chemical composition chromite $\left(\mathrm{FeCr}_{2} \mathrm{O}_{4}\right.$ or $\mathrm{FeO} \cdot \mathrm{Cr}_{2} \mathrm{O}_{3}$ ) is an admixture of two varieties, ferro-chromite, rarely magnesio-chromite: about 32 to 47 wt.\% of $\mathrm{Cr}_{2} \mathrm{O}_{3}$ with total iron between 24 wt. $\%\left(5 \% \mathrm{Fe}_{2} \mathrm{O}_{3}\right.$ and $\left.19 \% \mathrm{FeO}\right)$ and $28 \%$ $\left(4 \% \mathrm{Fe}_{2} \mathrm{O}_{3}\right.$ and $\left.23 \% \mathrm{FeO}\right)$ and $\mathrm{MgO}$ between 12 and 40 wt.\% - all approximative values for one of the mineral resources in central and south regions of Africa [11].

The chromite sand is not a natural sand. It is produced from the above-cited mineral in the form of rocks, and after crushing and sifting and is available as the loose material of the average particle - granulometry AFS 46-55. It is met some other composition data (presumably other geological deposit) indicating the typical oxide contents: $\mathrm{Cr}_{2} \mathrm{O}_{3}: 46 \%, \mathrm{FeO} 27 \%, \mathrm{Al}_{2} \mathrm{O}_{3}: 15 \%$ and $\mathrm{MgO}: 10 \%$ [12]. An important condition irrespectively of the deposit source is limited content of $\mathrm{SiO}_{2}$ and $\mathrm{CaO}$ (less than $1 \%$ and $0,3 \%$ ).

It should be emphasized that despite the price many times exceeding that for the quartz sand, the technological challenges, especially for heavy steel castings determine the choice of this matrix of sand mould.

The important characteristics of the chromite sand are: for the density of mineral from 4500 to $4800 \mathrm{~kg} / \mathrm{m}^{3}$, its sand bulk density is approximately $2600 \mathrm{~kg} / \mathrm{m}^{3}$, and additionally its $\mathrm{pH}$ value is neutral, as well as the demand on acid/alkaline. The desirable properties for applications in the foundry related to quartz sand are: a higher fire resistance (melting temperature range from 1760 to $1982^{\circ} \mathrm{C}$ ), greater thermal conductivity - approx. $20 \%$ and also greater relative thermal effusivity ( $\left.b_{\text {chromite sand }} / b_{\text {quartz sand }}\right)-$ approx. $1,13\left(\mathrm{~b}\left[\mathrm{Ws}^{1 / 2} / \mathrm{m}^{2} \mathrm{~K}\right]\right)$ and smaller linear expansion $-0,6 \%$ in $1200^{\circ} \mathrm{C}$ (quartz - approx. $1,5 \%$ ).

It also should be emphasized too that chromite is used especially as it has the ability to resist metal penetration by molten steel and oxides. This is mainly due to the chilling ability of chromite to make the oxides (eutectics) less fluidity when steel is in contact with the mould (wettability resistance).

To agglomerate the chromite sand grains can be used in principle all traditional organic and inorganic binders used in foundry, keeping in mind the acid/alkaline conflict which occurs in cases when there is applied in the same mould the different types of resin/hardener [1].

A recuperation of chromite sand from the circulating moulding sand also has an economic aspect, because it can be used again as a matrix to make a new chromite moulding sand. The condition is to obtain the high purity chromite $\left(\max \mathrm{SiO}_{2}\right.$ $<2 \%$ ), what is possible when use the professional installations for the recovery by magnetic method [2].

The chromite sand as raw material stands out sharply edge shape of the grains and slightly shiny black surface. After the annealing of the real mould by steel (the layer adjacent to the casting) or in laboratory furnace (above $700^{\circ} \mathrm{C}$ ) the grains cover by gray tarnish (iron oxides). It is considered that the chromite still maintains its utility value, but is rarely used $100 \%$ of recuperated chromite to produce a new moulding sand (added from 30 to $60 \%$ of "fresh" chromite).

The installation for magnetic chromite separating (with varying degrees of oxidation of the grains surface) was subject to several modifications described in [2]. Diagram of the final installation was shown in Fig.1 and in Fig. 2a [13].

Ordering literature information on the features of magnetic materials, one can say that magnetic properties of mineral may be classified into four groups based on their attraction to a magnetic field (magnetic susceptibility), namely [14]:

- diamagnetic: repels a magnet, zero dipole moment,

- paramagnetic: random arrangement of magnetic dipoles in a crystal structure; drawn weakly to a magnet (example: olivine, chromite),

- ferromagnetic: similar to paramagnetic but has domains that align easily in the presence of an external magnetic field; therefore strongly attracted to a magnet (example: $\mathrm{Fe}$ ),

- ferrimagnetic: antiparallel ionic spin moments; permanent magnetic domains are there present (example: magnetite). 


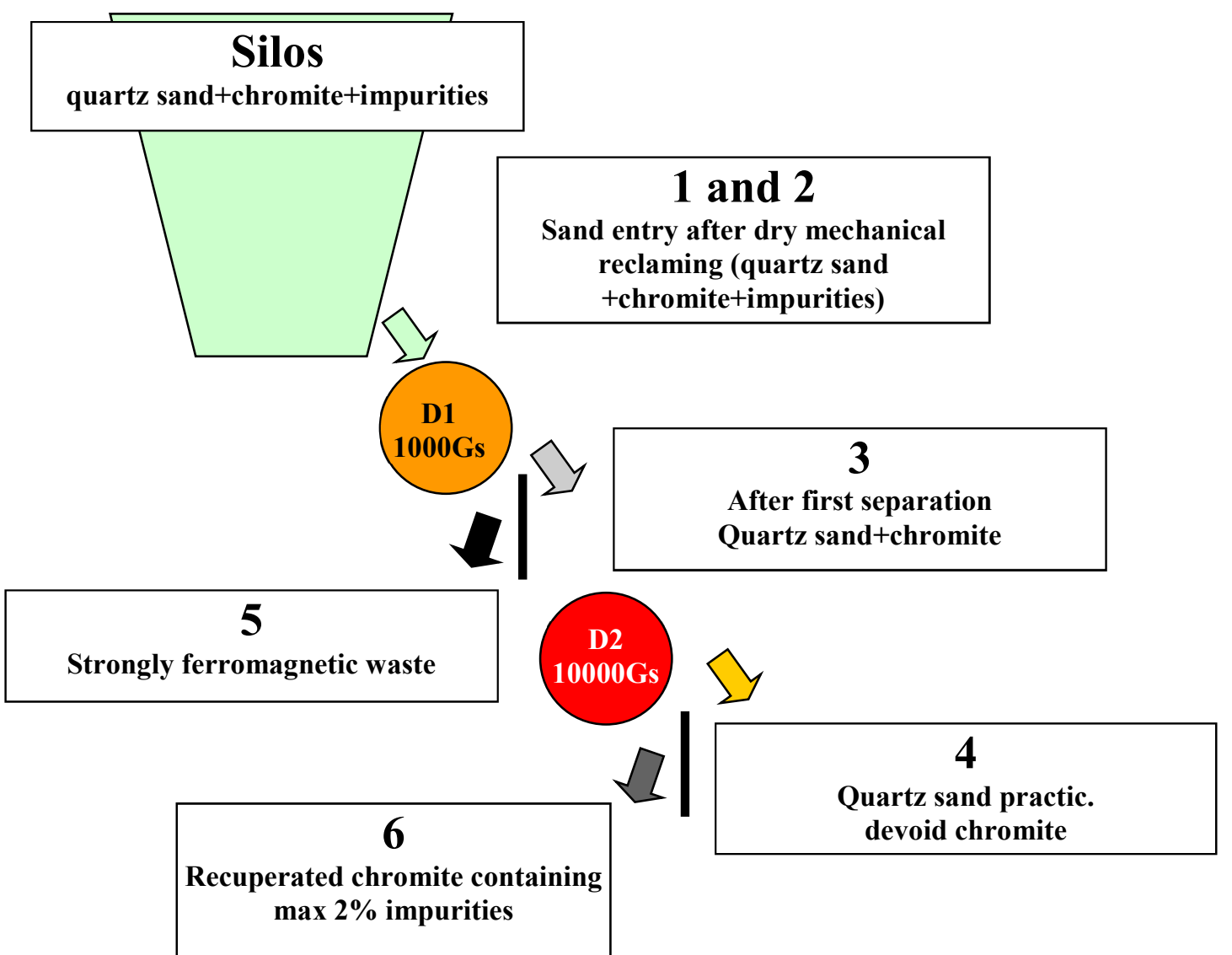

Fig. 1. Scheme of installation for recuperation of chromite sand with two magnetic drums (streams 1 to 6) [13]

The discussion that has been undertaken with representatives of global companies distributors of chromite at Ferry-Capitain company regarding the effect of the degree of oxidation of chromite on its magnetic properties caused to undertake the preliminary tests by the authors described in [13]. In Fig.2 it was shown the visual evidences that the subjecting of chromite by high-temperature heat treatment causes the increase of magnetic properties.

a.

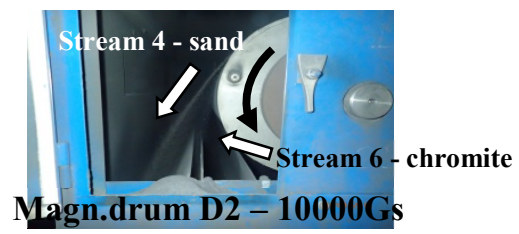

b.

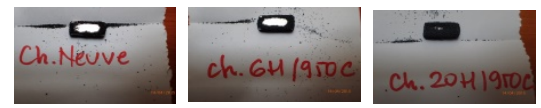

Fig. 2. View of magnetic drum: a - really installation and bvisual neodymium magnet test results of chromite samples

subjected to various heat treatments (new chromite and comparably with chromite after two thermal treatment kinds which is more and more magnetic)
In [15] has been shown that magnetic susceptibility as the degree to which a material can be magnetized in an external magnetic field is time-temperature dependent conditions of such treatment (Fig.3).

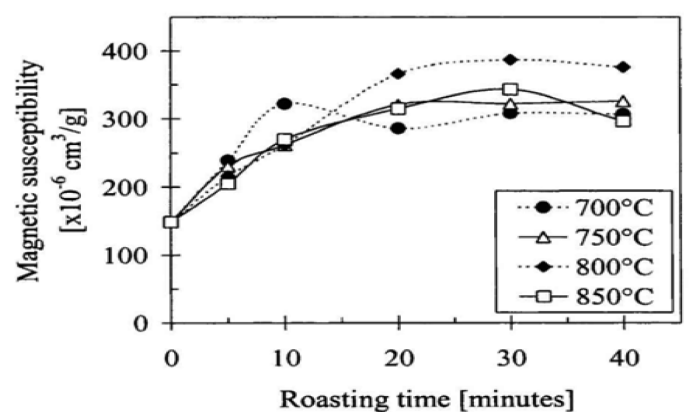

Fig. 3. Magnetic susceptibility of chromite sample after calcination at different temperatures for different time intervals in air [15]

Additionally, if the ratio between the induced magnetization and the inducing field is expressed per unit volume, volume susceptibility ( $\mathrm{k}$ ) is defined as $\mathrm{k}=\mathrm{M} / \mathrm{H}$, (where $\mathrm{M}$ is the volume magnetization induced in a material of susceptibility $\mathrm{k}$ by the 
applied external magnetic field $\mathrm{H}$; susceptibility volume is a dimensionless unit).

The chromite sand content in the circulating moulding sand is determined using a gravimetric method using a bromoform [16]. The sedimentological analysis must be carried out following the standard procedures (drying, splitting)

A density separation is based on the fact that different minerals have different densities. Thus, if a mixture of minerals with different densities (chromite 4500-4800 kg/m $\mathrm{m}^{3}$, quartz 2700 $\mathrm{kg} / \mathrm{m}^{3}$ ) can be placed in a liquid with an intermediate density. Suitable liquids for density separation is bromoform (density about $2840 \mathrm{~kg} / \mathrm{m}^{3}$, other source). The procedure is very simple [15]. Bromoform is a dense liquid with a molecular weight $252,8 \mathrm{~g}$, practically insoluble in water, with a density of 2890 $\mathrm{kg} / \mathrm{m}^{3}$ at ambient temperature [14].

Unfortunately, the rules of hygiene and safety determine quite accuracy conditions of use of this material. Foundries are not equipped with fume cupboards and staff do not have a license to perform tests using bromoform. They are frequently obliged to order to external specialized laboratories of this kind of tests.

This causes an increase of costs and leads to reduce the number of tests (e.g. once every two weeks or a month). The frequency tracking an amount of chromite circulating moulding sand is very limited, related to number of the other parameter testings such as: granulometry, amount of dust, loss on ignition index, $\mathrm{pH}$ and acid/alkalin demand.

Therefore, it was undertaken to develop the methods which let to determine even the approximate content of chromite sand in the circulating moulding sand.

\section{New metods of chromite content estimation in moulding reclaimed sands}

The first idea was to use the image analysis of the mixture (digital photo of flat tested sand layer) and the typical software for metallographic structure analysis application (using a NISElements BR system known in the past as Lucia system). The module for determining the gray level at two levels: 0-75 and 0100 was used. The samples of the mixture of fresh (new) quartz sand with an addition of chromite sand (proportion from 2 to $15 \%)$ served as the calibration patterns. The selected results were shown in Fig.4.
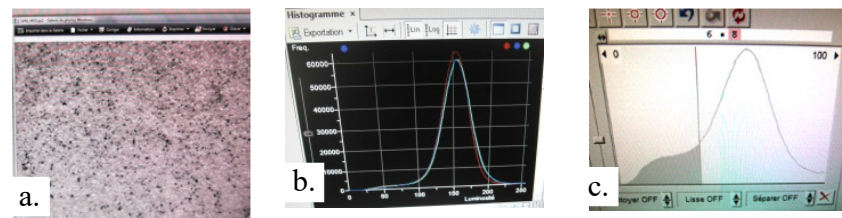

Fig. 4. Results of image analysis of the mixture of quartz sand $(90 \%)+$ chromite sand $(10 \%)-$ (sequence of screen photographs,

NIS-Elements BR system), a. digital photo, b. total statistical

distribution of grayscale levels (0-255) - mean value 149,89, c. participation of distribution area $0-100-4,35 \%$

It has been found that the use of photometric method applying NIS-Elements BR software can be taken as the substitute method, however, the limitation is due to the fact that it could be applied only to the fresh quartz sand (yellow color). For the black circulating moulding sand (the presence of contaminants adhering on the surface of grains), this method is not useful.

Utilizing the paramagnetic properties of chromite, it was proposed a method of effective and simultaneously operationally uncomplicated. This method can be used for circulating moulding sands.

The method consists of taking about $1000 \mathrm{~g}$ of sanding mould of selected layer of the moulding sand from a silos and the use of a probe containing neodymium magnets, as shown in Fig. 5. The procedure of probe calibration and final calibration curve is shown in Fig.6.

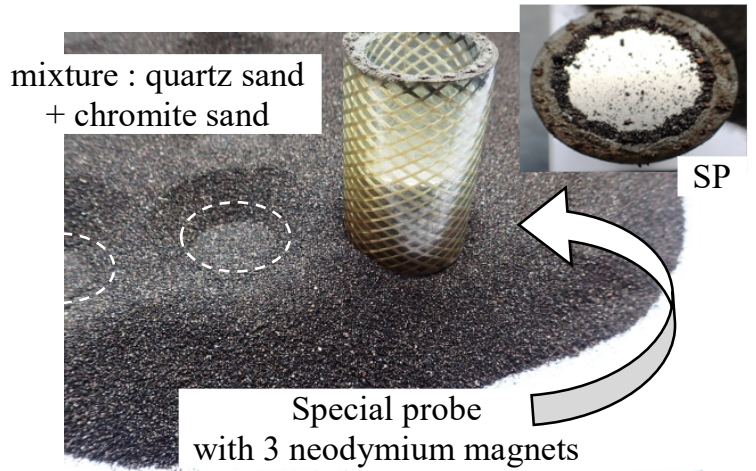

Fig. 5. The principle of chromite sand quantity estimation using a magnetic probe (5 prints) and view the work surface probe (SP)

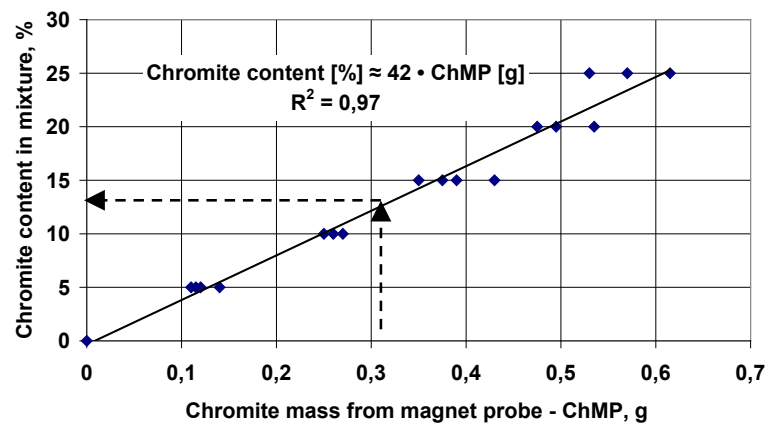

Fig. 6. Calibration curve for use of Chromite Magnet Probe (ChMP); every new probe requires an individual calibration; one example of sand chromite content [\%\%] estimation is shown

\section{Summary}

The paper presents the genesis of a new method for determing the amount of the chromite sand in the moulding sand volume after dry reclamation of circulating moulding sand in the foundry which uses simultaneously the acid and alkaline resin binder systems in the same mould. The determination of the amount of the chromite sand (three tests on the same sample) does not take longer than 10 minutes and it can be realized in any frequency of a week or month. It was prepared the instruction of this method and were used it in the production conditions for current 
monitoring of reclaim plant correct operation in the Ferry-Capitain Metallurgical Group. The relatively low dispersion of the results of three chromite tests realized for one sample and comparing with the results obtained in the aim of validation of this method in the external laboratory (gravimetric separation method using a bromoform) confirmed the efficiency of the new magnetic method with the application of probe with neodymium magnets. This method is the subject of patent application [17].

\section{Acknowledgements}

The research was partially supported by Poznan University of Technology support 02/25/DSBP/4187 and by Metallurgical Group - Ferry-Capitain CIF Company.

\section{References}

[1] Ignaszak, Z., Herzog, T., Millot, A., Prunier. J-B. (1995). Etude sur les hypthèses et les perspectives de la régénération et de la valorisation des sables usés de fonderie. Proceedings of International Conference "Nowoczesne Technologie Odlewnicze - Ochrona Środowiska" AGH Kraków.

[2] Ignaszak, Z., Millot, A., Prunier. J-B. (1997). Recuperation of chromite from circulating moulding sand. Technological and economical aspect, Pro. II Międzynarodowej Konferencji Nowoczesne Technologie Odlewnicze-Ochrona Środowiska, AGH (in Polish).

[3] Ignaszak, Z., Prunier, J-B. \& Piault. R. (1999). Exploitation experience of pneumatic transport system in French founderies conditions. Solidification of Metals and Alloys. 40 (in Polish).

[4] Ignaszak, Z. (2000). Thermal reclamation of chemical binding moulding sands. Furan moulding sand example. Proceedings of III International Conference "Nowoczesne Technologie Odlewnicze-Ochrona Środowiska". (in Polish).

[5] Ignaszak, Z., Prunier, J-B. \& Piault. R. (2002). Thermal reclamation and binder sands recycling using the pneumatic transport. Archives of Foundry. 5. 64-73, (in Polish).
[6] Ignaszak, Z., Stark, U., Ziętkiewicz, S., Nieskurski. B. (2005). Identification of thermal reclamation binder moulding sand parameters in aluminum alloy foundry, Procedings of Conference „Transport Pneumatyczny 2005”, Ed. PAN Oddział Katowice 2005, 104-118. (in Polish)

[7] Ignaszak, Z. (2004). Analyze of sand quality parameters in reclamation system plant. Operating report for Srem Foundry, Poznan, (in Polish).

[8] Ignaszak, Z. \& Prunier, J-B. (2006). The practice of furan moulding sands quality optimization made of reclaim sand in cast iron foundry. Przeglad Odlewnictwa. 7-8, 310-314 (in Polish).

[9] http://www.sandb.com/wp-ontent/uploads/18_Abreuvage.pdf

[10] Abubakre, O.K., Muriana R.A. \& Nwokike. P.N. (2007). Characterization and beneficiation of Anka chromite ore using magnetic separation process. Journal of Minerals \& Materials Characterization \& Engineering. 6(2), 143-150.

[11] http://www.amcolmetalcasting.com. AMCOL Metalcasting Illinois 60192 USA.

[12] Centre Technique des Industries de la Fonderie (CTIF), Manuel des sables à prise chimique (de la mise en œuvre au recyclage). (1994). Edition by Centre Technique des Industries de la Fonderie. Sèvres/Paris.

[13] Ignaszak, Z. (2014). Pousierre dans la chromite recuperee (rapport final), Unpublished report, Ferry-Capitain, November.

[14] http://www.apkzone.in/xinhai (China), Mineral Separation Techniques and http://www.apkzone.in/index.php.

[15] Steenkamp. G. \& Pistorius, P.C. (2003). Kinetics of chromite vs. ilmenite magnetization during oxidative roasting of ilmenite concentrates. Journal of The South African Institute of Mining and Metallurgy. October, 501-507.

[16] Gujar, A.R. and others. (1998). Ilmenite, Magnetite and Chromite Beach Placers from South Maharashtra, Central West Coast of India. Resource Geology, 60(1), 71-86.

[17] Ignaszak, Z. (2015). Procede de determination de la quantite de chromite par utilisation d'aimants neodymes. Patent application as « Lettre Soleau ». Ferry-Capitain. August. 